\title{
Community Service Satisfaction Index Information System Using the Web-Based CSS Method (Community Satisfaction Survey) at Statistics Center in Tapaktuan
}

\author{
Salya Rater ${ }^{\mathrm{a}, 1, *}$, Fardiansyah $^{\mathrm{b}, \mathrm{c}, 2}$, Safrijah $^{\mathrm{b}, 3}$ \\ a South Aceh Polytecnic, Jl. Reklamasi Pantai Tapaktuan and 23711, Indonesia \\ ${ }^{1}$ salya.rater@gmail.com*; 2fardian.poltas@gmail.com; ${ }^{3}$ safrijah.poltas16@gmail.com
}

ARTICLE INFO

Article history:

Accepted

Keywords

CSI

CSS Method

\section{ABSTRACT}

The Community Satisfaction Index (CSI) is data and information about the level of community satisfaction from quantitative and qualitative measurement results in obtaining services from public service administrators by comparing their expectations and needs. Public service providers, community service units are faced with many related things. This application system uses the Community Satisfaction Survey (CSS) method, which is an activity carried out using a questionnaire as a research instrument. Community satisfaction services held are not aimed at seeking profit but must prioritize service quality in accordance with the demands, expectations and needs of the people being served. Public service providers are faced with many things related to improving service quality through good performance and quality of product. And this public service dominates the related agencies. To measure the performance of public service units, elements / indicators are needed to provide an assessment of the performance results of public service units. This system is designed to find out the results of public service performance at the Central Statistics Agency (BPS) in Tapaktuan which is measured based on the unknown Public Service Satisfaction Index. The Community Satisfaction Index (CSI) system aims to determine the level of service performance in Tapaktuan Central Statistics Agency (BPS) in providing services to the community, as well as a vehicle for absorbing community aspirations in the form of suggestions, hopes, as well as complaints about the services that have been provided so far. to be used as guidelines for policy makers, programs and strategies for improving services. One of the efforts to improve the quality of public services as mandated in the Republic of Indonesia Law Number 25 year 2000 concerning the National Development Program, in the Decree of the Minister of State Apparatus Empowerment Number 14 of 2017 concerning guidelines for preparing community satisfaction surveys of public service administration units.

Copyright (C) 2021 Politeknik Aceh Selatan. All rights reserved.

\section{Introduction}

The Community Satisfaction Index is data and information about the level of community satisfaction from quantitative and qualitative measurement results in obtaining services from public service administrators by comparing their expectations and needs. Public service providers, community service units are faced with many related things [1].

Based on the results of observations made at BPS Tapaktuan, there are several problems including in terms of service which is still using the manual system. This system is ineffective and efficient because the processing of services to the public / agencies has to wait for hours. Often times service providers are not in place for some reason or other, so that the public service process is public which should be the responsibility of the administering agency. 
To measure the performance of public services at BPS Tapaktuan, supporting methods and indicators are needed which are of course needed to improve service quality. The method used in this final project assignment is to distribute questionnaires to consumers (communities / agencies) where the data will become a reference and basis for measuring community satisfaction with BPS services. In determining the indicators in this final project assignment refers to the Law of the Republic of Indonesia Number 25 of 2000 concerning the National Development Program, in the Decree of the Minister of State Apparatus Empowerment Number 14 on 2017 concerning guidelines for preparing community satisfaction surveys for public service administration units [1].

\section{Theoritical Review}

\section{A. Information System}

Information system is a system within an organization that meets the needs of daily transaction data processing that supports operations and is material and strategic activities required for certain external parties [2]. The Community Satisfaction Index is a measurement result of the Community Satisfaction Survey in the form of numbers. Numbers are determined on a scale of 1 (one) to 4 (four) [3]. Services are all service activities carried out by public service providers as an effort to meet the needs of service recipients, as well as in the context of implementing the provisions of laws and regulations [1].

Methods are often defined as ways or paths that must be taken or taken by a person to achieve the expected goals. The method comes from the Greek word "Methodos" which means the way or the way to go. The function of the method is as a tool to achieve goals or how to do and make things [4].

The Community Satisfaction Survey is a comprehensive measurement of the level of public satisfaction with the quality of services provided by public administrators [1].

\section{B. Central Bureau of Statistics (CBS)}

The Central Bureau of Statistics (CBS) is a Non-Departmental Government Institution that is directly responsible to the President. Previously, CBS was the Central Bureau of Statistics, which was formed based on Law No. 6/1960 on the Census and Law No. 7/1960 on Statistics. As a substitute for the two laws, Law 16/1997 on Statistics was enacted. Based on this Law which was followed up by the legislation under it, formally the name of the Central Bureau of Statistics was changed to the Central Bureau of Statistics. [5].

\section{Methodology}

Before you begin to format your paper, first write and save the content as a separate text file. Keep your text and graphic files separate until after the text has been formatted and styled. Do not use hard tabs, and limit use of hard returns to only one return at the end of a paragraph. Do not add any kind of pagination anywhere in the paper. Do not number text heads-the template will do that for you.

Finally, complete content and organizational editing before formatting. Please take note of the following items when proofreading spelling and grammar:

\section{A. Preparation of Community Satisfaction Index Using the SKM Method}

The compilation of the Community Satisfaction Index (IKM) uses a tool in the form of a questionnaire to the community using services as direct respondents, the questionnaire questions include 9 elements which refer to the Decree of the Minister of State Apparatus Empowerment Number 14 of 2017 concerning guidelines for preparing community satisfaction surveys for public service administering units, namely:

- Service Requirements, are requirements that must be met in administering a type of service, both technical and administrative requirements

- System, Mechanism and Procedure are service procedures performed for service providers and recipients, including complaints.

- Service Time, is the period required to complete the entire service process of each type of service. 
- Fees, are cost that charged to service recipients in managing and / or obtaining services from the operator, the amount of which is determined based on an agreement between the organizer and the community.

- Product Specifications for the type of service are the results of services that have been provided and received in accordance with predetermined provisions. This service product is the result of each type of service specification.

- Implementer Competence, is the ability that must be possessed by the executor including knowledge, expertise, skills and experience.

- Implementation Behavior, is the attitude of the officer in providing services.

- Complaint Handling, Suggestions and Inputs, namely the procedures for handling complaints and follow-up actions.

- Facilities and Infrastructure, namely anything that can be used as a tool in achieving goals and objectives. Infrastructure is anything that is the main support for the implementation of a process. Means are used for moving objects and infrastructure for immovable objects.

\section{B. Preparation of Survey Instrument (Questionnaires)}

In compiling the Community Satisfaction Index, a question (questionnaire) was used as a tool to collect data on the satisfaction of the community receiving services. The questionnaire was prepared according to the type of service being surveyed and the data to be obtained from the type or service unit. The design of the answer in each question on the service elements in the questionnaire uses a Likert scale, which is the scale most widely used in research in the form of surveys. The level of service quality ranges from very good to not good. The distribution of answers is divided into 4 (four) categories, namely:

- Not good, given a perception score of 1 .

- Enough, given a perception score of 2 .

- Good, given a perception score of 3 .

- Very good, given a perception score of 4 .

\section{Research Method}

The method used to conduct a community satisfaction index survey is measurement using a Likert scale. The Likert scale is a psychometric scale commonly used in questionnaires and is the scale most widely used in survey research. This method was developed by Rensis Likert. The Likert scale is a scale that can be used to measure the attitudes, opinions and perceptions of a person or group of people towards a type of public service. On a Likert scale, respondents were asked to determine their level of agreement with a statement by selecting one of the available options.

\section{System Design}

- Use Case Diagram Design

Use case diagrams are diagrams that present the process from the user's point of view. Use cases consist of users and actors [6].

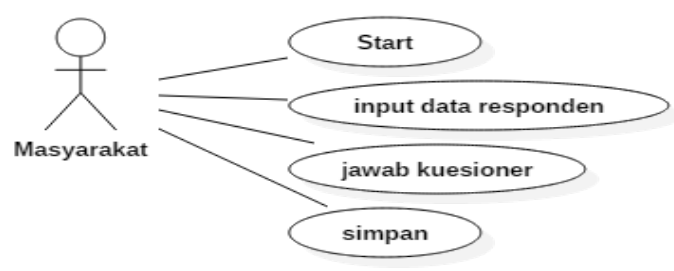

Figure 1. Usecase for User 


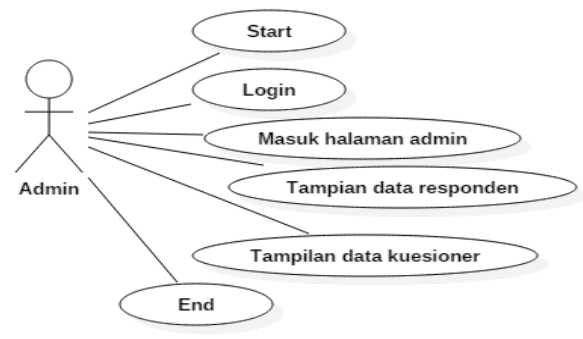

Figure 2. Usecase for Admin

- Flowchart Design

A program flowchart is a chart that describes in detail the steps of the program process. The program flowchart is called from the derivation of the system flowchart [7].

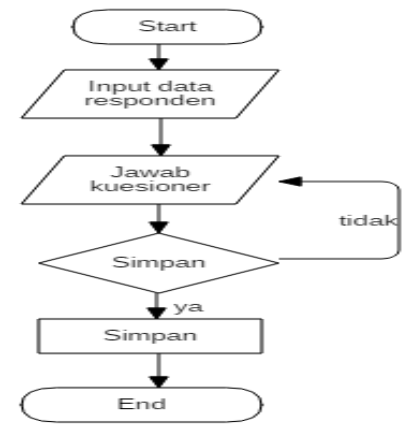

Figure 3. Flowchart for User

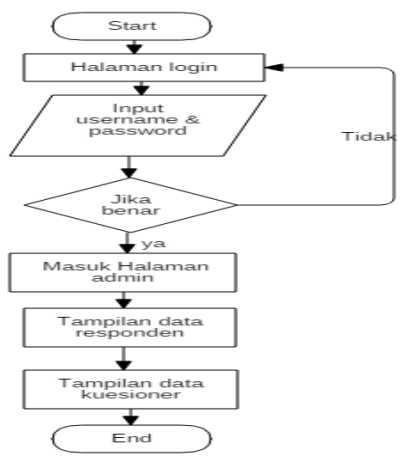

Figure 3. Flowchart for Admin

E. Research Conducting Tool

In conducting the preparation of final project, this research involved several tools that the authors use, among others :

- Hardware

The limitations of the hardware used in this system are as follows, Processor : Intel(R)

Celeron(R) CPU N2820@2.13GHz 2.13 GHz, RAM : 2 GB

- Software 
Windows 7, Php dan Mysql, Xampp, Notepad ++.

\section{Results and Discussion}

\section{A. Homepage Display}

This main page display is the application start page that will be seen by the public / respondents who will access the application or who will fill out a questionnaire in terms of service. This page will display a dashboard menu and a questionnaire filling menu.

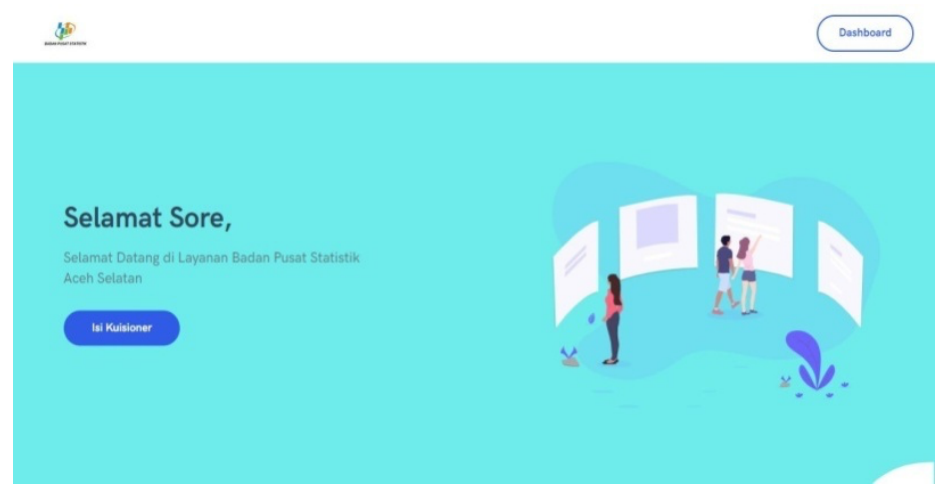

Figure 4. Homepage Display

\section{B. Identify the Headings}

The questionnaire form is the last process before the officer switches to other respondents. And on the questionnaire form, respondents / the public are welcome to assess the perceived performance at the Central Bureau of Statistics by checking / clicking one of the buttons provided. And if one of them has not been filled in, a warning will appear. Below is a display of the survey form and warning form.

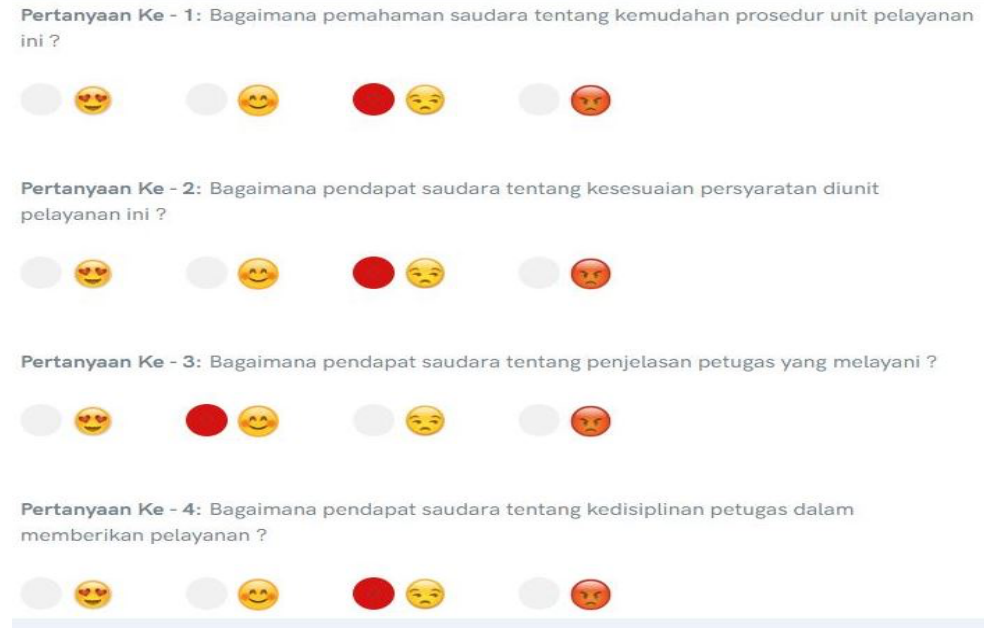

Figure 5. Questionnaire Form

\section{Critics and suggestions form}

The critic's form is a response in the form of critics accompanied by descriptions and good and bad considerations of a result or something. And suggestions are expressions in the form of suggestions or suggestions in order to solve something constructive. If all options have been checked / filled in, then the next process is sending, sending is the last process of filling out the entire survey data. 
Figure 6. Critics and Suggestions Form

\section{Login Form}

The login form serves to maintain the security of an application. When activating the application, the login form will appear first, if the username and password match the database, the data input form will be active. The login menu or security menu has a security form that functions to maintain security from data theft. This menu consists of a username and password.

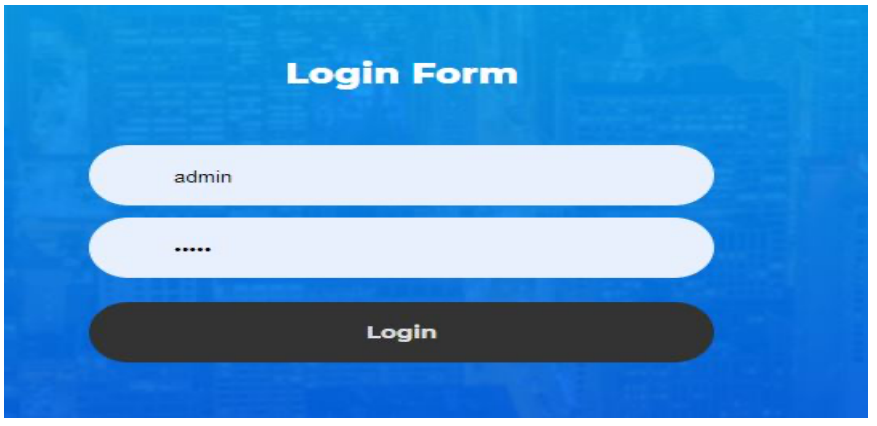

Figure 7. Login Form

\section{E. Dashboard Menu}

The dashboard menu is a display of the overall public satisfaction index data, the purpose of making a dashboard display is to observe the community satisfaction index about the services available at the Tapaktuan Central Bureau of Statistics. Below is the formula for calculating the overall results of the respondent's data. Below is the overall result of the respondent's data. And respondent data converted into excel.

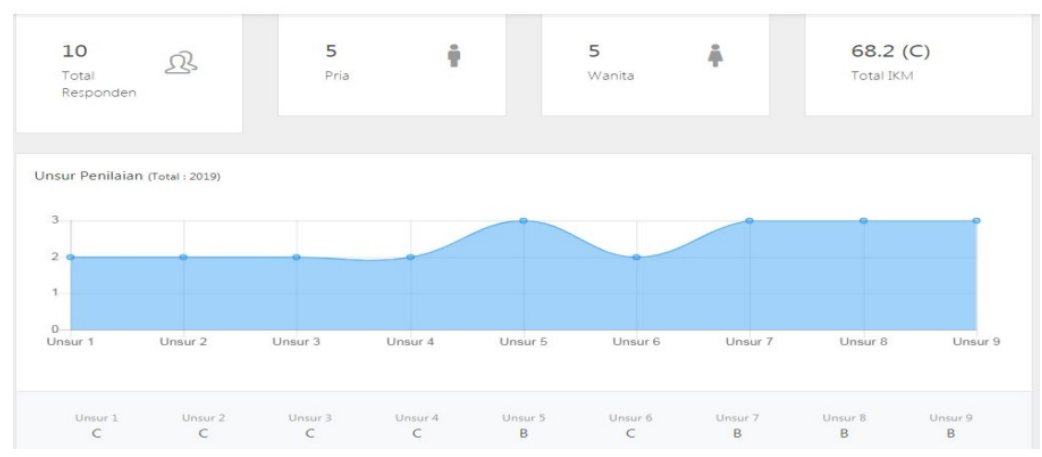

Figure 8. Overall results of respondent data 


\begin{tabular}{|c|c|c|c|c|c|c|c|c|c|c|c|c|}
\hline & & & \multicolumn{4}{|c|}{ Lampiran Data Responden } & & & & & & \\
\hline & & & & & & & & & & & & \\
\hline Responden & Unsurl & unsur2 & Unsur3 & 3 Unsur4 & 4 Unsur5 & Unsur6 & Unsur? & Unsur8 & unsur9 & Nilai Indeks per responden & Nilai dasar & Nilai IKM setelah dikonrersi \\
\hline Responden 1 & 3 & 2 & 4 & 1 & 3 & 1 & 4 & 2 & 2 & 2,42 & 25 & 60,5 \\
\hline Responden 2 & 3 & 4 & 3 & 4 & 3 & 3 & 4 & 3 & 3 & 3,30 & 25 & 82,5 \\
\hline Responden 3 & 2 & 2 & 2 & 3 & 3 & 2 & 2 & 4 & 4 & 2,64 & 25 & 66,0 \\
\hline Responden 4 & 3 & 3 & 3 & 3 & 3 & 3 & 3 & 3 & 3 & 2,97 & 25 & 74,3 \\
\hline Responden 5 & 1 & 1 & 1 & 3 & 3 & 2 & 2 & 3 & 3 & 2,09 & 25 & 52,3 \\
\hline Responden 6 & 4 & 4 & 4 & 4 & 4 & 4 & 4 & 4 & 4 & 3,96 & 25 & 99,0 \\
\hline Responden 7 & 2 & 2 & 2 & 2 & 2 & 2 & 2 & 2 & 2 & 1,98 & 25 & 49,5 \\
\hline Responden 8 & 1 & 1 & 1 & 3 & 3 & 3 & 3 & 3 & 3 & 2,31 & 25 & 57,8 \\
\hline Responden 9 & 2 & 2 & 2 & 2 & 4 & 4 & 4 & 4 & 4 & 3,08 & 25 & 77,0 \\
\hline Responden 10 & 3 & 2 & 4 & 1 & 3 & 1 & 4 & 2 & 3 & 2,53 & 25 & 63,3 \\
\hline Cotal Nilai keseluruhar & 2,4 & 2,3 & 2,6 & 2,6 & 3,1 & 2,5 & 3,2 & 3 & 3,1 & 2,73 & 25 & 68,2 \\
\hline
\end{tabular}

Figure 9. Respondent data converted to excel

\section{F. Respondent Data Display}

In this respondent data display, the data of respondents who have participated in the service will be displayed. In the respondent's data display, the admin can see the respondent's data directly and the results of the per respondent's assessment, for example the admin can see the extent of the response from each respondent, whether the respondent feels good or bad service. With the following formula:.

So to find out the CSI value is calculated as follows: $(\mathrm{a} \times 0,11)+(\mathrm{b} \times 0,11)+(\mathrm{c} \times 0,11)+(\mathrm{d} x$ $0,11)+(\mathrm{e} \times 0,11)+(\mathrm{f} \times 0,11)+(\mathrm{g} \times 0,11)+(\mathrm{h} \times 0,11)+(\mathrm{i} \times 0,11)=$ index value $(\mathrm{X})$. So the index value $(\mathrm{X})$ service results can be summarized as follows. CSI index after being converted $=$ index value $\mathrm{x}$ base value $\mathrm{X} \times 25=\mathrm{Y}$

\begin{tabular}{|c|c|c|c|c|c|c|c|c|c|c|c|c|}
\hline & & & & \multicolumn{3}{|c|}{ Lampiran Data Responden } & & \multirow[b]{2}{*}{ Unsur8 } & \multirow[b]{2}{*}{ unsur9 } & \multirow[b]{2}{*}{ Nilai Indeks per responden } & \multirow[b]{2}{*}{ Nilai dasar } & \multirow[b]{2}{*}{ Nilai IKM setelah dikonvers } \\
\hline Responden & Unsurl & unsur2 & Unsur3 & Unsur4 & Unsur5 & Unsur6 & Unsur? & & & & & \\
\hline Responden 1 & 3 & 2 & 4 & 1 & 3 & 1 & 4 & 2 & 2 & 2,42 & 25 & 60,5 \\
\hline Responden 2 & 3 & 4 & 3 & 4 & 3 & 3 & 4 & 3 & 3 & 3,30 & 25 & 82,5 \\
\hline Responden 3 & 2 & 2 & 2 & 3 & 3 & 2 & 2 & 4 & 4 & 2,64 & 25 & 66,0 \\
\hline Responden 4 & 3 & 3 & 3 & 3 & 3 & 3 & 3 & 3 & 3 & 2,97 & 25 & 74,3 \\
\hline Responden 5 & 1 & 1 & 1 & 3 & 3 & 2 & 2 & 3 & 3 & 2,09 & 25 & 52,3 \\
\hline Responden 6 & 4 & 4 & 4 & 4 & 4 & 4 & 4 & 4 & 4 & 3,96 & 25 & 99,0 \\
\hline Responden 7 & 2 & 2 & 2 & 2 & 2 & 2 & 2 & 2 & 2 & 1,98 & 25 & 49,5 \\
\hline Responden 8 & 1 & 1 & 1 & 3 & 3 & 3 & 3 & 3 & 3 & 2,31 & 25 & 57,8 \\
\hline Responden 9 & 2 & 2 & 2 & 2 & 4 & 4 & 4 & 4 & 4 & 3,08 & 25 & 77,0 \\
\hline Responden 10 & 3 & 2 & 4 & 1 & 3 & 1 & 4 & 2 & 3 & 2,53 & 25 & 63,3 \\
\hline Iotal Nilai keseluruhar & 2,4 & 2,3 & 2,6 & 2,6 & 3,1 & 2,5 & 3,2 & 3 & 3,1 & 2,73 & 25 & 68,2 \\
\hline
\end{tabular}

Figure 10. Display Data Per Respondent in excel

Sample sample of respondent data converted from excel to applications. Below is the data for respondent 1

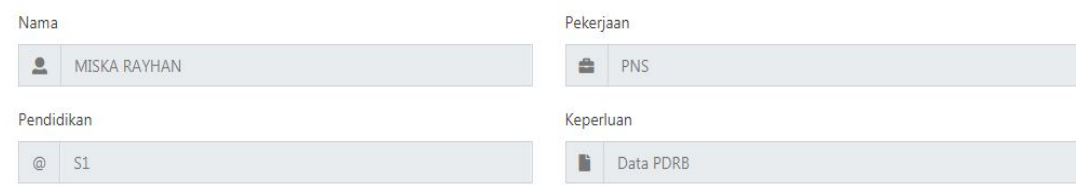

Figure 11. Respondent Data 


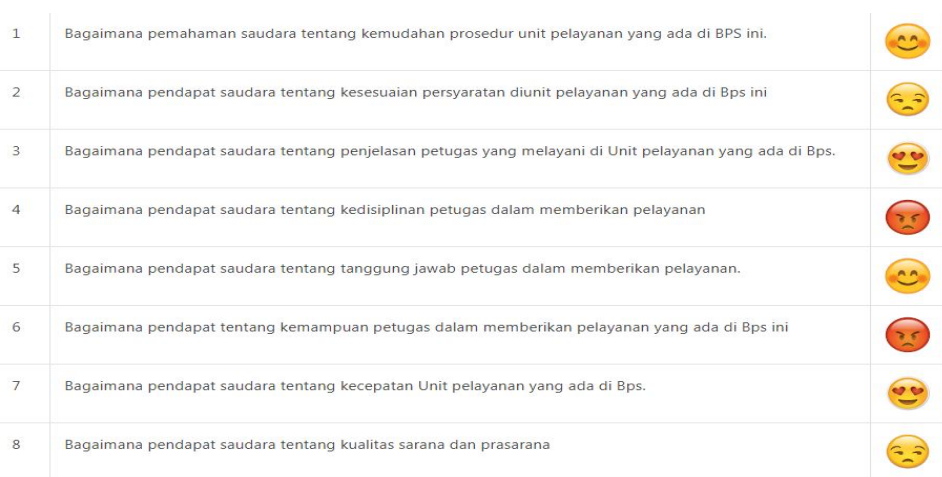

Figure 12. Results of Respondents' Assessment of Services

The picture above is a data question that has been filled in by the respondent and the results of the graph are the same as the excel data.

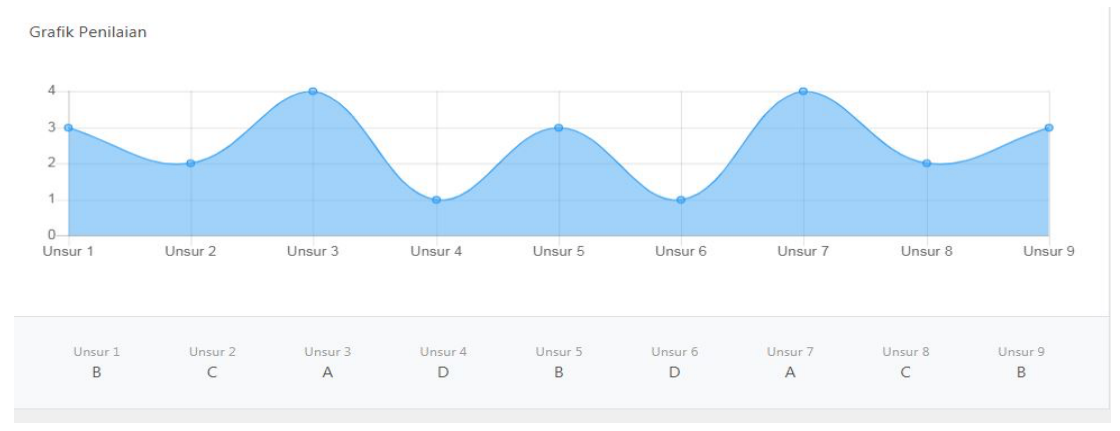

Figure 13. Chart of Data Per Respondent

\section{Conclusion}

Based on the objectives and test results, conclusions can be drawn as follow:

1. This aplication systems can help the community in providing suggestions, hopes, and complaints about the services provided so far, to be used as guidelines for policies, programs and strategies for improving services.

2. This application system uses a community satisfaction survey method, namely activities carried out using a questionnaire as a tool in compiling a community satisfaction index.

3. This application system already uses a digital system, initially the system used at the Central Bureau of Statistics is still manual which still uses paper as a tool for filling out questionnaires.

4. The existence of this system makes it easier to calculate the overall results of the respondents compared to the manual system which is calculated using a calculator as a calculation tool.

\section{Suggestion}

The suggestions are as follows:

1. The display of this application uses a graphic as a reference for evaluating the overall respondent's data, so it is hoped that in the future this application can be made a graphical assessment system for respondent.

2. Several questions can be made as evaluation material to assess the criteria for the element in question, so that in the future this application can make an assessment classification 


\section{References}

[1] Abnur Asman. Peraturan Menteri Pendayagunaan Aparatur Negara Dan Reformasi Birokrasi Repubik Indonesia, Nomor 14 Tahun 2017, Tentang Penyusunan Survei Kepuasan Masyarakat Unit Penyelenggara Pelayanan Publik.

[2] Minarni Dkk (2011). Sistem Informasi Perpustakaan Berbasis Web Pada Politeknik Kesehatan Padang. Jurnal Teknologi Informasi dan Pendidikan ITP, 3(1), 102-109.

[3] Ayu Feby, Desriyen. Pembuatan indeks subjek tugas akhir mahasiswa D4 dari tahun 2013-2017 di perpustakaan Politeknik Negeri Padang. Jurnal informasi perepustakaan dan kearsipan. Vol.5, no. 1, maret 2017. Seri C.

[4] Https://www.pelajaran.co.id/2016/16/pengertian-dan-defenisi

metode-menurut-para-ahliterlengkap.html. Diakses pada tanggal 11 juli 2019.

[5] Https:/acehselatankab.bps.go.id. Diakses pada tanggal 22 mei 2019.

[6] Anggara Banu Primadita. 6305120073. Aplikasi Restoran Terintegrasi Menggunakan Java, Mysql, dan Tampilan Augmented Reality. Restoran Aplication Integrated Use Java Aplication, Mysql and Augmented Reality Display. D3 Teknik Telekomunikasi, Fakultas Ilmu Terapan, Universitas Telkom. ISSN : 2442-5826. E-Proceeding of Applied Science : Vol.1, No.3 Desember 2015|Page 2684

[7] Siswanto, Zulita Leni Natalia, Aspriyono Hari. Dosen Tetap Fakultas Ilmu Komputer Universitas Dehasen Bengkulu. Jurna Media Infortama Vol.8 No.2 September 2012. 121.ISNN :1858-2680. 